\title{
Effectiveness of BPHTB Administration Services at the Makassar City Regional Revenue Agency
}

\author{
Risma Niswaty ${ }^{1}$, Seha ${ }^{2}$, Sitti Hardiyanti Arhas ${ }^{3}$, Muh. Nasrullah ${ }^{4}$, Muh. Darwis ${ }^{5}$ \\ Universitas Negeri Makassar ${ }^{1,2,3,4,5}$ \\ Email: risma.niswaty@unm.ac.id
}

(Received: 28 July 2020; revised: 14 August 2020; published: 23 September 2020)

\begin{abstract}
Administrative services by Fees for Acquisition of Land and Building Rights at the Makassar City Regional Revenue Agency office have resulted in a good performance. The purpose of this research is to describe the effectiveness of administrative services of acquisition duties on land and building rights at the Makassar City Regional Revenue Agency office. This research is a quantitative descriptive. The results showed: shows that the effectiveness of administrative services for land and building rights in the office of the Regional Revenue Agency of Makassar City with the effective category of timeliness which is categorized as effective is $94.61 \%$, the accuracy of services categorized as effective is $71.38 \%$, politeness and friendly categorized as effective $94 \%$, ease of getting services that were categorized as effective $94.46 \%$, and comfort in getting services that were categorized as quite effective $54.30 \%$. This proves that the administrative service of acquisition fees on land and building rights (BPHTB) at the Makassar City Regional Revenue Agency office has been able to carry out its duties and responsibilities and can implement an administrative service system properly.
\end{abstract}

Keywords: Effectiveness, service, administration. BPHTB

\section{INTRODUCTION}

Nowadays with the very rapid rate of technological development in all fields (Aras, Syam, Jasruddin, Akib, \& Haris, 2017; Said, Akib, Salam, \& Baharuddin, 2017; Saleh, Jamaluddin, \& Arhas, 2019), demands an institution or agency to further improve all internal lines, which in turn have implications for success and achieving organizational goals by expected expectations. Internal improvements can be made in the form of human resource management, which is the most important element of the organization (Bircan \& Gençler, 2015; Boer \& Blaga, 2012; Masini, 1990; Sze, Bluth, Bender, \& Parikh, 2017) in addition to the resources that support other organizations.

State-owned enterprises (BUMN) as one of the many organizations in Indonesia that also provide services to the community (Aneta, Akib, Kadji, \& Basri, 2014; Astuti, Darwis, Saleh, \& Baharuddin, 2019), of course, you have to manage as much as possible the human resources in it to meet the wants and needs of consumers in this case society.

BUMN must be able to provide satisfaction to the community as consumers and provide a good image in the eyes of the community by providing quality services. Seeing this situation, the government is trying to make BUMNs try to improve the situation by providing the best service to the community. With good service, it is hoped that the community as users or customers of the services offered by these government-owned companies will be satisfied. Satisfaction levels are always related to the services provided (Ayu, Niswaty, Darwis, \& Arhas, 2019; Nasrullah, Siraj, \& Arhas, 2020). Service quality is a dynamic condition related to products, services, people, processes, and the environment that meet or exceed expectations. 
It can be said that service quality is a form of assessment in the use of services at the level of service received with the expected service level (Mirdawati, Niswaty, Darwis, \& Salam, 2018; Niswaty, Manno, \& Akib, 2015). For organizations or institutions, the key is adjusting or exceeding the expectations of the quality of services desired by the community or service users. The quality of service received by users or the community in the form of information can affect behavior and loyalty in the future. As in administrative services at the Makassar Regional Revenue Agency Office is the SKPD (Regional Work Unit). In the Makassar City Government, the Makassar City Regional Regulation Number 8 of 2016, concerning: "Formation and Composition of the Makassar City Regional Perngkat, where the Regional Revenue Agency has the task of helping to carry out supporting functions of government affairs in the financial sector which is the regional authority".

The Makassar Regional Revenue Agency is a company engaged in the tax sector, which is one part of its field of BPHTB, which is the tax imposed on the acquisition of rights to land and buildings. Where stated in Law Number 21 the Year 1997 which was later amended by Law of the Republic of Indonesia Number 20 the Year 2000, namely "Regulating new objects that were previously irregular in the previous Law, namely regarding inheritance, business mergers, and business burning".

BPHTB (Fees for Acquisition of Land and Building Rights) is also regulated in Law of the Republic of Indonesia Number 28 of 2009, regarding Regional Taxes and Regional Levies. This is regulated in detail in the seventeenth part of articles 85-93, namely: Fees for Acquisition of Land and Building Rights (BPHTB) for land rights. BPHTB is imposed only at the time of sale and purchase of land, but also for any acquisition of rights over land and buildings (exchange, grants, inheritance, land entry into the company, etc.).

The problem nowadays is that we often encounter many government offices that provide unsatisfactory services for those who receive services and often utter bad words. Many things make the community as service recipients feel dissatisfied when being served by an institution, one of which is employee disrespect, indifference, indifference, highpitched words. In providing good service, the expertise and skills possessed by BPHTB employees are needed so that not only will it smooth the flow of administration in the institution and the satisfaction of the people served will also have an impact on the performance of the employees themselves.

From the problems in the field described above, it becomes the basis for researchers to research "BPHTB Administration Services at the Office of the Regional Revenue Agency of Makassar City". In providing good service, the expertise and skills possessed by BPHTB employees are needed so that not only will it smooth the flow of administration within the institution and the satisfaction of the people served will also have an impact on the employee's performance.

\section{METHOD}

This research is a type of descriptive quantitative research where the researcher tries to produce findings through various data collection methods, namely observation, questionnaires, and documentation. Research variables are a person's attributes, objects which have variations from one person to another or one object to another. As stated by Hatch and Farhady (1981) in (Arhas \& Suprianto, 2020)(Akib, Guntur, \& Salam, 2016), that "Research variables are indicators that become the object of research or research centers in a study ". In this research variable that will be studied is the effectiveness of BPHTB Administration Services at the Makassar City Regional Revenue Agency. As for 
calculating the score, the researcher determines the standard measurement of indicators as suggested by Arikunto and Fitriani in Rumaikeuw (2015), namely: "76\% -100\% is categorized as good, $56 \%-75 \%$ is categorized as sufficient, $40 \%-55 \%$ is categorized as unfavorable. , and less than $40 \%$ are categorized as bad ".

This study does not test the relationship or conduct between the two variables, but only describes the quality of BPHTB services at the Makassar City Regional Revenue Agency. In this study, the techniques used in the field data collection process were primary data and secondary data. Primary data is data obtained by conducting direct research on the object of research using observation techniques, distributing questionnaires, and documentation. The observation technique in this study is a direct observation of research subjects and recording events and behavior in a natural, original, and not contrived manner regarding the quality of ongoing administrative services. The questionnaire in this study is in the form of a questionnaire, wherein the questionnaire there are questions or written statements addressed to respondents to be answered. The documentation technique in this research is secondary data collection from document recording or written evidence. The data analysis technique used in this research is descriptive analysis technique using the mean and percentage formula.

\section{RESULT AND DISCUSSION}

To determine the level of effectiveness of Administration Service for Acquisition of Rights and Land Acquisition at the Regional Revenue Agency Office of Makassar City, a questionnaire instrument is used as the main data collection tool. The questionnaire is arranged in the form of a statement of 12 question items by providing five choices.

\section{On-Time Service}

Timeliness is measured based on the sub-indicators of Openness of service completion time and timeliness of service processes which are presented in Table 1 to Table 2 as follows:

Table 1.

The openness of Service Completion Time

\begin{tabular}{lcc}
\hline Answer category & Frequency (f) & Percentage $(\%)$ \\
\hline Very good & 44 & 67,69 \\
Good & 20 & 30,76 \\
Pretty good & 1 & 1,53 \\
Not good & 0 & 0,00 \\
Not very good & 0 & 0,00 \\
\hline Total & 65 & 100,00 \\
\hline
\end{tabular}

Source: Results of Questionnaire Number 1

The data in questionnaire 1 shows that the sub-indicator of the openness of service completion time with the delivery of information is given before carrying out the service process, indicating that of the 65 respondents, 44 respondents or 67.69 percent answered very well, 20 respondents or 30.76 percent who answered well and 1 respondent or 1.53 percent who answered quite well.

Thus, those who answered very well and well on the results by questionnaire 1 were 64 respondents with the reason that the respondents thought that if the openness of the service completion time was very good, then 1 respondent answered quite well because the file completion time was too long to complete. From the results of the respondents' answers, it can be concluded that all notary staff felt that the submission of time for file 
completion processing had been informed.

To find out the responses of respondents regarding the timeliness of the service process, it can be seen in Table 2 .

Table 2.

Timeliness of Service Process Delivery

\begin{tabular}{lcc}
\hline Answer category & Frequency $(\mathrm{f})$ & Percentage $(\%)$ \\
\hline Very good & 52 & 80 \\
Good & 13 & 20 \\
Pretty good & 0 & 0,00 \\
Not good & 0 & 0,00 \\
Not very good & 0 & 0,00 \\
\hline Total & 65 & 100,00 \\
\hline
\end{tabular}

Source: Results of Questionnaire Number 2

The data in questionnaire 2 shows that the sub-indicator of the accuracy of the delivery of the service process time with the employee's statement has communicated to the notary staff, showing that of the 65 respondents, 52 respondents or 80 percent answered very well, 13 respondents or 20 percent answered well.

Thus, those who answered very well and well on the results of the processing of questionnaire 2 totaled 65 respondents on the grounds of the accuracy of the delivery of the service process time which was communicated to the notary or notary staff in the form of direct communication, direct communication was carried out during the service process.

From the results of respondents' answers, where many notary staff felt very good and only a small proportion felt good, the openness of the service completion time with this could be categorized as very good.

\section{Accuracy of Service}

Service accuracy is measured based on sub-indicators of minimizing errors in performing administrative services which are presented in Table 3 to Table 4 as follows:

Table 3.

Minimizing Errors in File Entry

\begin{tabular}{lcc}
\hline Answer category & Frequency (f) & Percentage $(\%)$ \\
\hline Very good & 17 & 26,15 \\
Good & 24 & 36,92 \\
Pretty good & 0 & 0,00 \\
Not good & 7 & 10,76 \\
Not very good & 1 & 1,53 \\
\hline Total & 65 & 100,00 \\
\hline
\end{tabular}

Source: Results of Questionnaire Number 3

The data in questionnaire 3 shows that sub-indicators minimize errors in file entry with employee statements communicating to notary staff, indicating that of the 65 respondents, 17 respondents or 26.15 percent answered very well, 24 respondents or 36.92 percent answered good, as many as 7 or 10.76 percent answered not well, and 1 or 1.53 percent answered very bad.

Thus those who answered very well and well on the results of questionnaire 3 were 41 respondents because the respondents thought that minimizing file entry errors was good, 
then 7 respondents answered badly because the respondent thought some employees were less focused in collecting files, and 1 respondent answered very badly because the respondent thought this employee sometimes made mistakes when collecting files.

From the results of the respondents' answers, it can be concluded that the notary staff felt that employees in minimizing errors in file entry were good. In line with research that has been conducted by researchers, it minimizes errors in file entry according to the observations made on January 15, 2020. see table 4.

To find out the responses of respondents regarding the file error repair mechanism,

Table 4.

File Repair Mechanism

\begin{tabular}{lcc}
\hline Answer category & Frequency (f) & Percentage $(\%)$ \\
\hline Very good & 24 & 36,92 \\
Good & 40 & 61,53 \\
Pretty good & 1 & 1,53 \\
Not good & 0 & 0,00 \\
Not very good & 0 & 0,00 \\
\hline Total & 65 & 100,00 \\
\hline
\end{tabular}

Source: Results of Questionnaire Number 4

The data in table 4 shows that the sub-indicators of file error correction mechanisms with employee statements have communicated to notary staff, indicating that of the 65 respondents, 24 respondents or 36.92 percent answered very well, 40 respondents or 61.53 percent answered well and 1 respondent or 1.53 percent answered quite well

Thus, from the results of questionnaire 4 who answered very well and well, there were 64 respondents because the respondent considered that the file error correction mechanism was good, then there was 1 respondent who answered quite well because the respondent thought that the repair of file errors was good enough.

\section{Courtesy and Hospitality}

Courtesy and friendliness are measured based on sub-indicators of appearance and behavior according to existing regulations and greeting taxpayers with $3 \mathrm{~S}$ (senyum, sapa, dan salam) which are presented in Table 6 to Table 7 as follows:

Table 5.

Appear and Behave According to the Existing Rules

\begin{tabular}{lcc}
\hline Answer category & Frequency (f) & Percentage (\%) \\
\hline Very good & 48 & 73,84 \\
Good & 17 & 26,15 \\
Pretty good & 0 & 0,00 \\
Not good & 0 & 0,00 \\
Not very good & 0 & 0,00 \\
\hline Total & 65 & 100,00 \\
\hline
\end{tabular}

Source: Results of Questionnaire Number 5

The data in table 5 shows that the sub-indicators look and behave according to the existing rules, indicating that of the 65 respondents, 48 respondents or 73.84 percent 
answered very well, 17 or 26.15 percent answered well.

Thus, from the results of the questionnaire 5 who answered very well and well, there were 65 respondents with the reason that the respondents thought that the appearance and behavior of employees were very good and by existing rules. In line with the research that has been conducted by researchers, that appearance and behavior are by the existing rules according to the observations made on January 15, 2020.

6:

To find out the responses of respondents regarding hospitality, it can be seen in Table

Table 6.

Greeting Taxpayers with 3S (Senyum, Sapa, dan Salam)

\begin{tabular}{lcc}
\hline Answer category & Frequency (f) & Percentage $(\%)$ \\
\hline Very good & 43 & 66,15 \\
Good & 22 & 33,84 \\
Pretty good & 0 & 0,00 \\
Not good & 0 & 0,00 \\
Not very good & 0 & 0,00 \\
\hline Total & 65 & 100,00
\end{tabular}

Source: Results of Questionnaire Number 6

The data in questionnaire 6 shows that the sub-indicator greets the taxpayer with 3 s (senyum, sapa, dan salam), shows that of the 65 respondents, 43 respondents or 66.15 percent answered very well, 22 respondents or 33.83 percent answered well.

Thus, from the results of questionnaire 6 which answered very well and well, there were 65 respondents because the respondents considered that employees were friendly to notary staff at the time of service and it could be concluded that employee friendliness was very good.

\section{Ease of Obtaining Service}

The ease of getting services is measured based on the sub-indicators of the availability of human resources in assisting services and supporting facilities such as online services which are presented in Table 7 to Table 8 as follows:

To find out respondents' responses regarding supporting facilities such as online services, it can be seen in Table 8:

\section{Table 7.}

Availability of Human Resources in Assisting Services

\begin{tabular}{lcc}
\hline Answer category & Frequency (f) & Percentage (\%) \\
\hline Very good & 46 & 70,76 \\
Good & 19 & 29,23 \\
Pretty good & 0 & 0,00 \\
Not good & 0 & 0,00 \\
Not very good & 0 & 0,00 \\
\hline Total & 65 & 100,00 \\
\hline
\end{tabular}

Source: Results of Questionnaire Number 7

The data in questionnaire 7 shows that the sub-indicator of the availability of human resources in helping services shows that of the 65 respondents, 46 respondents or 70.76 percent answered very well, 19 or 29.23 percent answered well. 
Thus, from the results of the questionnaire 7 who answered very well and well, there were 65 respondents because the respondents considered that at the time of handling the employee files they had done their job properly and responsibly, so it could be concluded that the ease of getting service was very good.

To find out the responses of respondents regarding supporting facilities such as online services, it can be seen in table 8:

Table 8.

Supporting Facilities Like Online Services

\begin{tabular}{lcc}
\hline Answer category & Frequency (f) & Percentage $(\%)$ \\
\hline Very good & 46 & 70,76 \\
Good & 19 & 29,23 \\
Pretty good & 0 & 0,00 \\
Not good & 0 & 0,00 \\
Not very good & 0 & 0,00 \\
\hline Total & 65 & 100,00 \\
\hline
\end{tabular}

Source: Results of Questionnaire Number 8

The data in questionnaire 8 shows that the sub-indicators of supporting facilities such as online services show that of the 65 respondents, 48 respondents or 73.84 percent answered very well, 17 or 26.15 percent of respondents answered well.

Thus, from the results of questionnaire 8 which answered very well and well, there were 65 respondents because the respondents considered that when validating files, they no longer had to wait for BPHTB administrative staff to validate but could be done alone where there was a computer provided by the Agency Agency. Makassar City Regional Revenue to facilitate notary staff in validating BPHTB management files and being connected to the internet network and BPHTB administrative service sites. With this, it can be concluded that supporting facilities such as online services are very good.

\section{Convenience in Obtaining Service}

Convenience in obtaining services is measured based on the equipment and safety sub-indicators which are presented in Table 9 to Table 12 as follows:

Table 9.

Availability of Queue Number

\begin{tabular}{lcc}
\hline Answer category & Frequency $(\mathrm{f})$ & Percentage $(\%)$ \\
\hline Very good & 0 & 0,00 \\
Good & 0 & 0,00 \\
Pretty good & 15 & 23,07 \\
Not good & 50 & 76,92 \\
Not very good & 0 & 0,00 \\
\hline Total & 65 & 100,00 \\
\hline
\end{tabular}

Source: Results of Questionnaire Number 9

The data in questionnaire 9 shows that the sub-indicator for the availability of queue numbers shows that of the 65 respondents, 15 respondents or 23.07 percent answered quite well, 50 or 76.92 percent of respondents answered not well.

Thus, from the results of questionnaire 9 who answered quite well and badly, there were 65 respondents because the respondents thought that the BPHTB administration 
service was not provided with a queue number, so the administrative service process did not go well. In the future, the Makassar City Regional Revenue Agency office, especially the BPHTB administrative service department, can provide a queue number so that the administrative service process can run well.

To find out the responses of respondents regarding seating equipment, it can be seen in Table 10.

Table 10.

Availability of Seats

\begin{tabular}{lcc}
\hline Answer category & Frequency $(\mathrm{f})$ & Percentage $(\%)$ \\
\hline Very good & 53 & 81,53 \\
Good & 11 & 71,50 \\
Pretty good & 1 & 1,53 \\
Not good & 0 & 0,00 \\
Not very good & 0 & 0,00 \\
\hline Total & 65 & 100,00 \\
\hline
\end{tabular}

Source: Results of Questionnaire Number 10

The data in questionnaire 10 shows that the sub-indicator for the availability of queue numbers shows that of the 65 respondents, 53 respondents or 81.53 percent answered very well, 11 respondents or 71.50 percent answered well, and 1 respondent or 1.53 who answered well enough.

Thus, from the results of the questionnaire 10 who answered very well and well, there were 64 respondents because the respondents considered that the seats provided during the file entry process were comfortable and very good, then 1 respondent answered quite well with the reason that the respondent considered the seat has provided is still insufficient when the service process is in normal conditions.

To find out the responses of respondents regarding air conditioning equipment, it can be seen in Table 11.

Table 11.

Air conditioner

\begin{tabular}{lcc}
\hline Answer category & Frequency $(\mathrm{f})$ & Percentage $(\%)$ \\
\hline Very good & 58 & 89,23 \\
Good & 7 & 10,76 \\
Pretty good & 0 & 0,00 \\
Not good & 0 & 0,00 \\
Not very good & 0 & 0,00 \\
\hline Total & 65 & 100,00 \\
\hline
\end{tabular}

Source: Results of Questionnaire Number 11

The data in questionnaire 11 shows that the sub-indicator for the availability of queue numbers shows that out of 65 respondents, 58 respondents or 89.23 percent answered very well, 7 or 10.76 percent answered well.

Thus, from the results of questionnaire 11 who answered quite well and badly, there were 65 respondents because the respondents thought that the air conditioner was very cool and comfortable while waiting for the file entry process to finish.

To find out the responses of respondents regarding security, it can be seen in Table 12: 
Table 12.

Availability of Parking Space

\begin{tabular}{lcc}
\hline Answer category & Frequency (f) & Percentage $(\%)$ \\
\hline Very good & 55 & 84,61 \\
Good & 9 & 13,84 \\
Pretty good & 1 & 1,53 \\
Not good & 0 & 0,00 \\
Not very good & 0 & 0,00 \\
\hline Total & 65 & 100,00 \\
\hline
\end{tabular}

Source: Results of Questionnaire Number 12

The data in questionnaire 12 shows that the sub-indicator for the availability of queue numbers shows that of 65 respondents, 55 respondents or 84.61 percent answered very well, 9 or 13.84 percent answered well.

Thus, from the results of the questionnaire 12 who answered very well and well, there were 64 respondents because the respondents considered that the security and parking at the Makassar City Regional Revenue Agency Office were very good, while only 1 respondent answered quite well because the respondent considered the parking lot less extensive. In line with research that has been conducted by researchers that the parking space provided by the Makassar City Regional Revenue Agency office is good and sufficient for taxpayers to park their vehicles.

\section{Discussion}

\section{Effectiveness of Administrative Services}

The word effective comes from the English language, namely effective, which means successful or something that is done can work well. According to Richard (2007: 270) in Katrina (2017), argues that "Effectiveness is the level of goals that an organization embodies". Meanwhile, administrative services are activities carried out to fulfill the needs of a person concerned with administration. Meanwhile, according to Hardiayansyah (2018), "Services are in the form of providing various forms of documents needed by the public, for example: Making identity cards (KTP), land certificates, birth certificates, death certificates, motor vehicle owner books (BPKB), registration letters). motorized vehicles (STNK), building permits (IMB), passports, and so on ". So the results of this study indicate that the level of administrative services at the Makassar City Regional Revenue Agency office is in the effective category.

\section{On-Time Service}

Timeliness of service is the timeliness in the service process provided by employees to taxpayers and the openness of service completion times, namely, waiting time during the file processing process. As for timeliness according to Chairil and Ghozali in Pérez (2017) defines timeliness (timeliness) is information for decision-makers when needed and before the information has lost its ability to influence a decision.

The results of research on administrative services of acquisition fees on land and building rights at the Makassar City Regional Revenue Agency office are in the effective category. This is supported by the results of the respondent's answer that the submission of the time for completing the files has been informed. 


\section{Accuracy of Service}

Service accuracy is to minimize errors made by employees in administrative services. The results of research on administrative services of acquisition fees on land and building rights at the Makassar City Regional Revenue Agency office are in the effective category. As for obeying Tjiptuno (2020) is to minimize service and transaction errors.

This is supported by the results of the answers of respondents and employees that employees in dealing with errors in inputting have been good and corrections in mistakes made by employees have also been done well.

\section{Courtesy and Hospitality}

According to (Tjiptuno 2020) courtesy and friendliness are the behavior of providing services with courtesy and friendliness in providing services. So politeness and friendliness are where employees look attractive by the rules set by the office concerned and greet taxpayers with smiles, greetings, and greetings.

The results of research on administrative services of acquisition fees on land and building rights at the Makassar City Regional Revenue Agency office are in the effective category. This is supported by the answers to the results from respondents that the appearance and behavior of employees are very good and according to existing rules and employees are friendly to notary staff when performing administrative services.

\section{Ease of Obtaining Service}

According to Tjiptuno (2020) namely the availability of needs that consumers are looking for. So the ease of getting services, which includes the availability of human resources in assisting administrative services and supporting facilities such as computers in searching for processed files.

The results of research on administrative services of acquisition fees on land and building rights at the Makassar City Regional Revenue Agency office are in the effective category. This is supported by the results of the respondent's answer that at the time of handling the employee files, they had done their job properly and responsibly, so that notary staff felt that the ease of getting service was very good.

\section{Convenience in Obtaining Service}

Convenience in obtaining services, namely taxpayers feel comfortable in the waiting room as long as their files are processed which include environmental cleanliness, a cool room, an information board on the flow of file management, and parking lots. The definition of facilities and infrastructure according to Anwar (2017) is one of the public service standards

The results of research on administrative services of acquisition fees on land and building rights at the Makassar City Regional Revenue Agency office are in the effective category. This is supported by the results of the respondents' answers that the seats provided during the file entry process are comfortable and very good, only the lack of queue numbers provided, but the administrative service process continues to run effectively.

\section{CONCLUSION}

Based on the results of the analysis and discussion that has been carried out, the results of the study can be concluded that the level of effectiveness of administrative services for acquisition duties on land and building rights at the Makassar City Regional 
Revenue Agency office is in the effective category. Judging from the aspects, namely timeliness which is categorized as effective, the accuracy of services which are categorized as effective, politeness and friendliness which are categorized as effective, ease of getting services that are categorized as effective, and comfort in obtaining services that are categorized as effective. This proves that the administrative services for the acquisition of land and building rights (BPHTB) at the Makassar City Regional Revenue Agency office have been able to carry out their duties and responsibilities and can implement a good administrative service system. The effective administrative service standard of land and building rights (BPHTB) at the Makassar City Regional Revenue Agency is seen in five aspects, namely: 1) timeliness, 2) accuracy of service, 3) politeness and friendliness, 4) ease of getting services, 5 ) comfort in obtaining service.

\section{REFERENCES}

Akib, H., Guntur, M., \& Salam, R. (2016). Civitas Academic Perception of "Blissful Services" for Recipient Postgraduate Program State University of Makassar, Indonesia. International Conference on Public Organization VI (ICONPO VI), 340350. Thammsat University, Tha Prachan Campus.

Aneta, Y., Akib, H., Kadji, Y., \& Basri, M. (2014). ORGANIZATIONAL TRANSFORMATION: THE REVITALIZATION OF THE ROLE AND FUNCTION FOR HUMAN RESOURCES (CASE STUDY OF PT. PLN AREA GORONTALO). International Journal of Academic Research, 6(3).

Anwar, H., Niswaty, R., \& Saleh, S. (2017). Pelayanan Penerbitan Buku Pelaut Berbasis Online. Jurnal Ilmiah Ilmu Administrasi Publik, 7(1), 11-24.

Aras, M., Syam, H., Jasruddin, J., Akib, H., \& Haris, H. (2017). The effect of service marketing mix on consumer decision making. International Conference on Education, Science, Art and Technology, 108-112.

Arhas, S. H., \& Suprianto, S. (2020). The Effectiveness of 6M Implementation at Artebo MSME. Jurnal Ad'ministrare, 6(2), 249-256.

Astuti, A., Darwis, M., Saleh, S., \& Baharuddin, A. (2019). Study of Employee Work Motivation at PT Bank Sulselbar Makassar Main Branch. Jurnal Office, 4(2), 37-52.

Ayu, A., Niswaty, R., Darwis, M., \& Arhas, S. H. (2019). Applying the Principles of Good Governance in the Efforts of Guiding Out-of-School Children at Social Service Offices Takalar Regency. Jurnal Office, 5(2), 51-58.

Bircan, İ., \& Gençler, F. (2015). Analysis of Innovation-Based Human Resources for Sustainable Development. Procedia - Social and Behavioral Sciences, 195, 13481354. https://doi.org/https://doi.org/10.1016/j.sbspro.2015.06.321

Boer, J., \& Blaga, P. (2012). A More Efficient Production using Quality Tools and Human Resources Management. Procedia Economics and Finance, 3, 681-689. https://doi.org/https://doi.org/10.1016/S2212-5671(12)00214-6

Masini, E. B. (1990). Human Resources in Developing Countries. Futures, 22(10), $1037-$ 1043. https://doi.org/https://doi.org/10.1016/0016-3287(90)90005-3

Mirdawati, J., Niswaty, R., Darwis, M., \& Salam, R. (2018). Keefektifan Pelayanan IMB Pada Kantor Dinas Penanaman Modal dan Pelayanan Terpadu Satu Pintu Kota Makassar The effectiveness of IMB Services at the Makassar City Investment Office and One Door Integrated Services at Makassar City.

Nasrullah, M., Siraj, M. L., \& Arhas, S. H. (2020). Intensification of Land and Building 
Tax Collection in The Barru Regency Revenue Service. 3rd International Conference on Social Sciences (ICSS 2020), 570-573. Atlantis Press.

Niswaty, R., Manno, J., \& Akib, H. (2015). An analysis of the public service performance based on human development index in makassar city, Indonesia. International Journal of Applied Business and Economic Research (IJABER), 13(6), 4421-4429.

Pérez, A., Santamaria, E. K., Operario, D., Tarkang, E. E., Zotor, F. B., Cardoso, S. R. de S. N., ... Volk, J. E. (2017). Faktor-Faktor Yang Mempengaruhi Ketepatan waktu (Timeliness) Penyampaian Laporan Keuangan. BMC Public Health, 5(1), 1-8.

Said, F., Akib, H., Salam, R., \& Baharuddin, A. (2017). An Analysis of Tourism Visit Trend. 2nd International Conference on Education, Science, and Technology (ICEST 2017). Atlantis Press.

Saleh, S., Jamaluddin, J., \& Arhas, S. H. (2019). IbM Supervisi Akademik Kepala Sekolah Dasar Berbasis Information Teknologi di Kecamatan Ulaweng Kabupaten Bone. Humanis, 18(2), 23-28.

Sze, G., Bluth, E. I., Bender, C. E., \& Parikh, J. R. (2017). Work-Related Injuries of Radiologists and Possible Ergonomic Solutions: Recommendations From the ACR Commission on Human Resources. Journal of the American College of Radiology, 14(10), 1353-1358. https://doi.org/https://doi.org/10.1016/j.jacr.2017.06.021

Tjiptuno, F. (2020). Mengenal Kualitas Pelayanan Secara Lengkap. Mengenal Kualitas Pelayanan Secara Lengkap.

Undang-Undang tahun 2009 tentang Pelayanan Publik, Pub. L. No. 25 (2009). 